\title{
UC's land-grant mission fuels nation's growth, prosperity
}

\author{
Rose Hayden-Smith \\ 4-H Youth, Family and Community Development Advisor \\ UC Cooperative Extension, Ventura County \\ ANR Sustainable Food Systems Strategic Initiative Leader
}

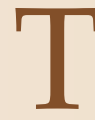
his year marks the sesquicentennial, or 150th anniversary, of four events key to American agriculture. In 1862, the United States Department of Agriculture (USDA) was created. Three pieces of legislation were also passed that would forever change the face of the nation: the Pacific Railroad Act, the Homestead Act and the Morrill Land-Grant College Act, which created America's land-grant institutions, including the University of California.

In 1862, America was in its second year of the Civil War, which threatened the nation's very survival. It was an unsettled time. Battles such as Shiloh - which would haunt American memory for decades - and Lincoln's preliminary Emancipation Proclamation left Americans feeling uncertain, but also in the case of the North, bravely charting a new direction that expressed optimism despite the war. At that time, farmers made up more than $50 \%$ of America's labor force; legislation such as the Morrill Act reflected their

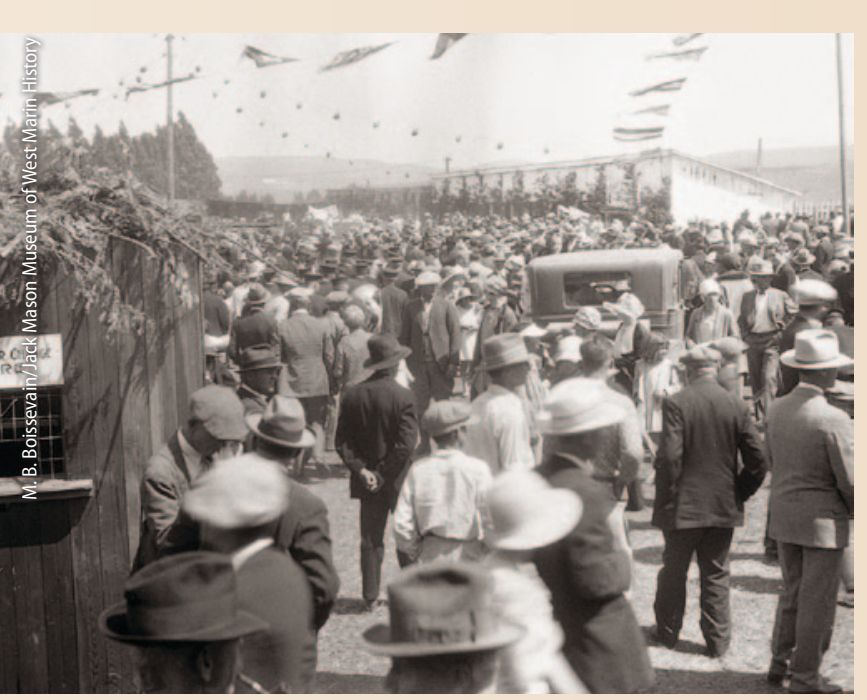

Agricultural societies were important early supporters of the land-grant system. Above, more than 10,000 people attended the Fifth Western Sonoma-Marin Dairy Cattle Show in Valley Ford, in 1927. Stock judges were from the University Farm at Davis, with over $\$ 1,800$ in cash prizes. importance, and reinforced the economic and social importance of agriculture to the nation's future. The Morrill Act also demonstrated the increasing importance of taking a more scientific approach to agricultural production and education.

The creation of the USDA (President Lincoln called it "the People's Department") institutionalized agriculture in the federal government; the agency was called "to diffuse among the people of the United States useful information on subjects connected with agriculture." While creation of the USDA was vital to American agriculture, it was the Morrill Act that was truly visionary. It enabled state governments to provide higher education in agriculture, science and mechanical arts. With its passage, all states were given blocks of land by the federal government that could be sold off by legislatures to fund public universities.

\section{Agricultural societies}

Farmers have always sought and shared agricultural knowledge. Agricultural organizations, often called societies, were designed to share agricultural knowledge, and they were prevalent in early America. Leaders in Philadelphia formed a society to promote agriculture in 1785; others quickly followed suit. Many of the letters written by General George Washington during the Revolutionary War focused on agricultural practices and production at his plantation. Like fellow founding father Thomas Jefferson, Washington was an agricultural innovator.

Agricultural experimentation was particularly strong among wealthy Southern growers in the period prior to the Civil War, due in part to a decline in soil fertility combined with decreasing cotton prices in the 1840s and 1850s. By the 1860s, there were more than 1,300 agricultural and horticultural societies in the United States; some states were also creating state boards and departments of agriculture. Agricultural fairs (and later, expositions) were popular, and served not only as places to market goods but also as sites for education and demonstration; George Washington encouraged the movement as early as 1796. The United States Agricultural Society was formed in 1851 and enjoyed significant success until the Civil War, when sectional differences made its operation impossible.

Farmers were hungry for knowledge. Publications such as the American Farmer (which came to press in 1819) filled some of the gaps. By the end of the 19th century, more than 3,000 agricultural publications had appeared at various times in the United States and Canada; most quickly failed. But through these efforts an increasing amount of information about agriculture was produced and shared, and more farmers were accessing agricultural information. This created a political culture that supported the idea of landgrant legislation.

\section{Land-grant legislation}

Justin Smith Morrill introduced the land-grant bill in the U.S. House of Representatives in December 1857; it was accepted by a narrow margin in April 1858. The Senate passed its own version, which was vetoed by President Buchanan, who acceded to Southern interests opposed to the perceived growth of federal power that the Act represented. Later, however, President Lincoln proved favorable to the idea of industrial education (in fact, agricultural education was a repeating campaign theme when he stumped for president). With the Southern congressional 


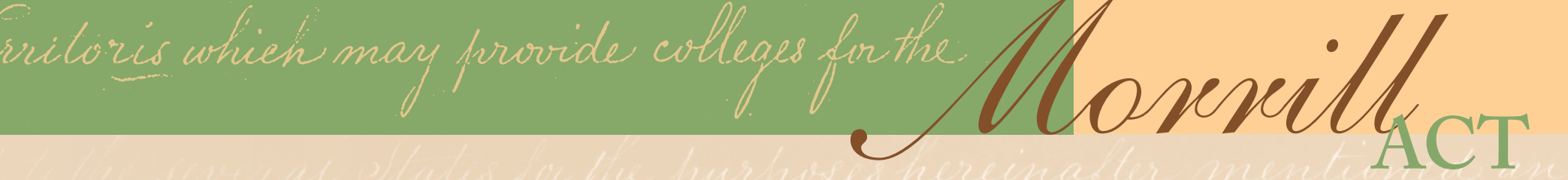

members who had opposed the Morrill Act now seceded from the Union, the legislation was reintroduced and signed into law on July 2, 1862

In September 1862, Iowa became the first state to accept the gift offered by the Morrill Act. By 1870, 37 states had signed on. A second Morrill Act in 1890 gave an additional boost to the land-grant system by fostering institutions serving African Americans in the Southern states.*

In California, the Morrill Act enabled the state to combine federal, state and private funds and efforts (the private College of California was part of the genesis of UC). This led to the creation of the University of California in 1868.

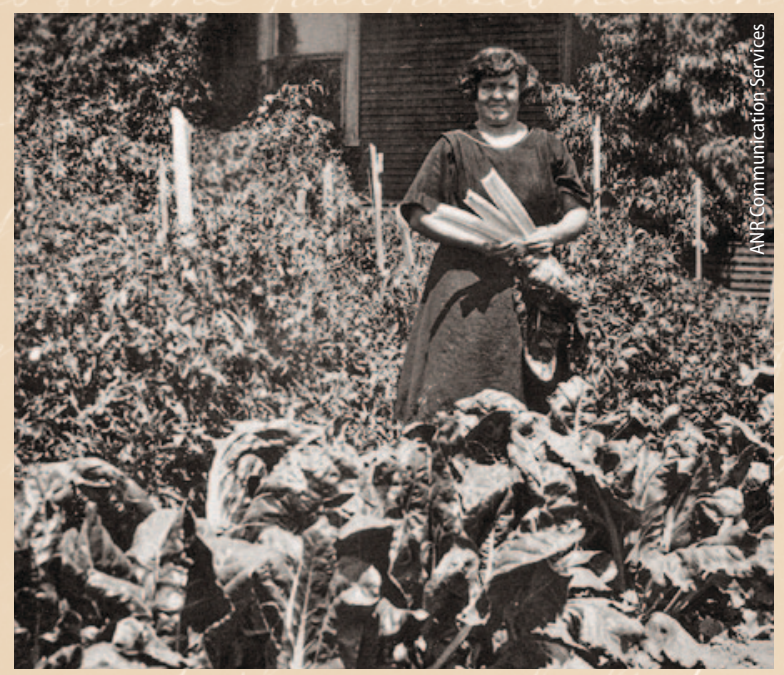

During World Wars I and II, UC Cooperative Extension supported the federal Victory Garden (shown) program in California. Nearly a million home vegetable gardens were planted and thousands of animals were raised for food.
Shortly after, a new campus was built on a tract of land near Oakland, called Berkeley. From humble beginnings, UC grew to become one of the world's pre-eminent educational institutions, providing the knowledge and technical education that helped California become one of the world's primary agricultural producers.

The Morrill Act was visionary, but it did not prove an immediate success. It took years for the states to take full advantage of the legislation, and even then, the connection between the production of knowledge at the land-grant institutions and its practical application by farmers was lacking. Some of the problems experienced, including low enrollments and a failure to teach practical agriculture, led to further legislation in the form of the Hatch Act in 1887t, which funded linked experiment stations to provide a practical place to help solve the problems of ordinary farmers. The 1905 State Farm Bill would fund establishment of the University Farm at Davisville in 1906, a teaching farm for UC Berkeley students. The Citrus Experiment Station in Riverside was founded in 1907; it proved vital to Southern California's developing citrus industry. In 1919, the California Legislature designated an existing teacher's college in Los Angeles as UC's southern branch; it became the UCLA campus in 1927 and offered some agricultural programs for decades. As a result of increased enrollment at UC due to the GI bill passed during World War II, the University Farm eventually evolved into the UC Davis campus. Likewise, the Citrus Experiment Station eventually gave rise to the UC Riverside campus. The original campus at UC Berkeley remained the flagship agricultural campus.

\section{Responding to wartime needs}

The period around World War I is one of the most interesting in the development of institutions such as UC, in part because of the passage of the Smith-Lever Act in 1914, which provided for "Cooperative Agricultural Extension Work," a federal, state and county funding partnership that gave rise to the Cooperative Extension Service. The importance of scientific agriculture and

* Corrected by California Agriculture April 13, 2012, after press run: "African Americans in the Southern states," not "African Americans and Native Americans."

† Corrected by California Agriculture April 16, 2013, after press run: "in 1887" not "in 1877. nation respond to wartime needs. In the quickly urbanizing nation, home food production again became a national priority, even an imperative. UC was involved in providing research, educational resources and training for the army of Victory Gardeners who arose from the civilian population to help raise food on the U.S. home front, encouraging local production and consumption in a national mobilization. It was thought that increased home food production and food conservation efforts would feed civilians, enabling America to increase its agricultural exports to foreign allies; this proved to be true.

School gardens. UC's groundbreaking efforts in school garden work and agricultural education, much done in the decade prior to World War I — including a program called the California Junior Gardeners offered in conjunction with the Berkeley School District - enabled a national program called

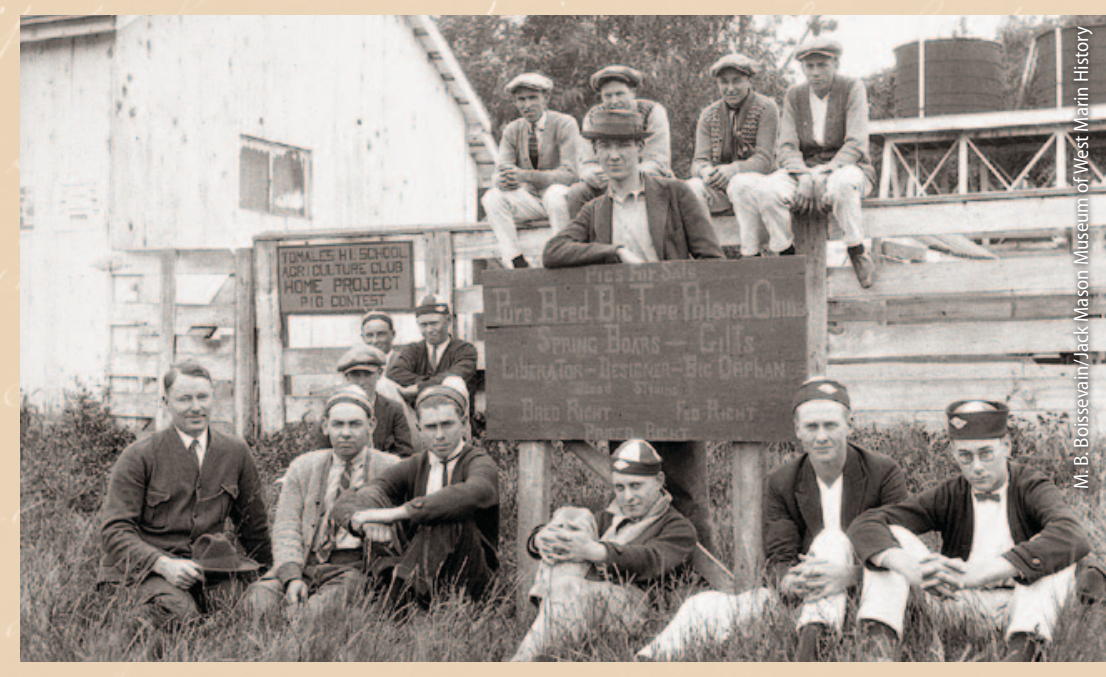

Cooperative Extension supports youth via 4-H, as well as nutrition and community development programs. Early in the 20th century, 4-H was an innovative way to introduce new agricultural technologies to farming communites. Above, the Tomales Joint Union High School Club, with leader Charles Hampton (left), raised and sold pigs in Marin County in 1924.

http://californiaagriculture.ucanr.edu • APRIL-JUNE 2012 
